\title{
WWW.Cell Biology Education
}

\section{Robert Blystone}

\author{
Department of Biology, Trinity University, San Antonio, Texas 78212
}

Submitted March 10, 2003; Accepted March 28, 2003

Cell Biology Education calls attention each quarter to several Web sites of educational interest to the biology community. The journal does not endorse or guarantee the accuracy of the information at any of the listed sites. If you want to comment on the selections or suggest future inclusions, please send a message to rblyston@trinity.edu. The sites listed below were last accessed on March 10, 2003.

\section{DOLAN DNA LEARNING CENTER}

\section{http://www.dnalc.org}

The DNA Learning Center is clearly a place where one can learn about DNA. There is material here that can instruct virtually anyone. To quote from the Center's Mission Statement: "The Dolan DNA Learning Center (DNALC) is the world's first science center devoted entirely to public genetics education and is an operating unit of Cold Spring Harbor Laboratory, an important center for molecular genetics research." The annual budget in support of the DNALC is nearly \$1 million and the money is well spent. Be prepared to learn and enjoy a wealth of genetics information.

The opening page provides the viewer six major choices to navigate the site (see Figure 1.) The "resources" path leads to seven very high-quality learning tools. The best known of these is "DNA from the Beginning." This resource is organized around 41 concepts equally divided among classical genetics, molecular genetics, and genetic organization and control. Each concept is supported by an animation, an interview with a key scientist associated with the concept, and links to expand the information base. A problem section poses brief

DOI: $10.1187 /$ cbe.03-03-0012

Corresponding author. E-mail address: rblyston@trinity.edu. questions about the concept. The concepts explored a range of concepts from a gene is on a chromosome to the structure of a chromosome.

Another superb resource is "Your Genes, Your Health." Fifteen genetic disorders are described in detail. Each disorder has something of interest, especially interviews with people who have the disorder. Too often genetic disorders are abstractions until you know someone with the disorder. The interviews put a face on the disorders, ranging from Marfan's syndrome to beta-thalassemia.

The "Biology Animation Library" resource contains six very useful animations, ranging from the polymerase chain reaction (PCR) to DNA Detective. Given the recent popularity of television forensics, users of the DNA Detective have a chance to identify criminals through DNA matching (see Figure 2.) Another resource is BioServers, which allows one to work with bioinformatics tools. BioServers will take a little time to learn but it provides a wonderful path into the bioinformatics realm.

The "products" path gives details of six low-cost products meant for classroom use. The CD version of "DNA from the Beginning" can be ordered with information found here. The "Genetic Computer Arcade" containing DNA Detective is another CD that may be of interest to student and teacher alike.

The "features" section has 59 news-like features that provide paths into the DNALC site. One of the features provides an interview with James Watson, who describes his role in the discovery of the structure of DNA. With this being the fiftieth anniversary year of the publication of the Watson and Crick article, the interview is extremely timely. The Features range from a discussion of eugenics to the actor Alan Alda describing his genes on The Gene Hunter, a television special on human genes.

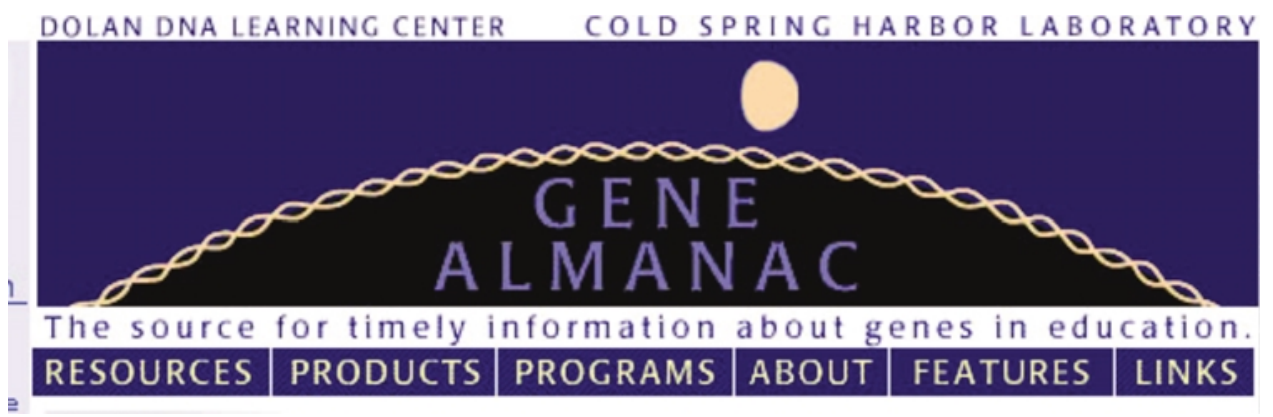

Figure 1. Dolan DNA Learning Center. 


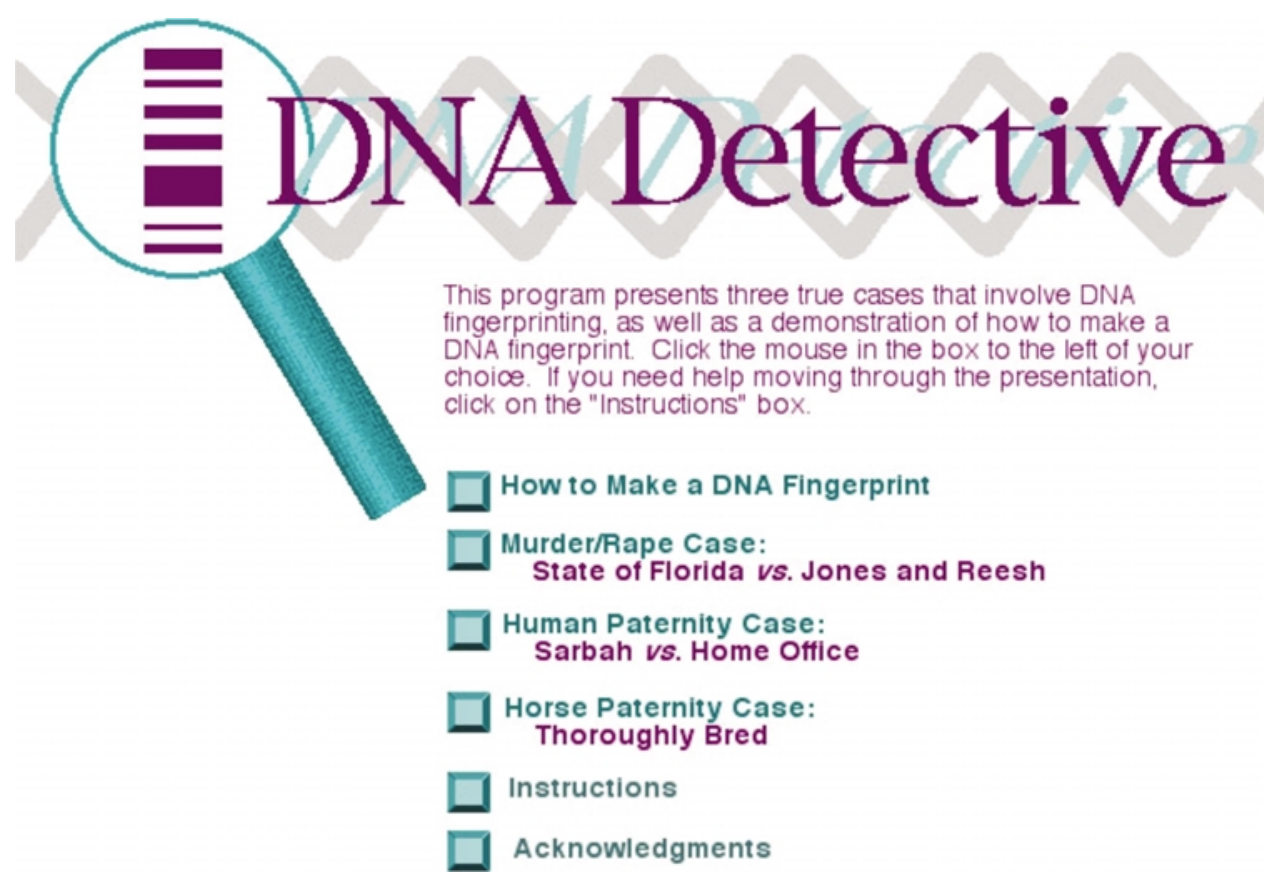

Figure 2. DNA Detective, in the "Biology Animation Library," Dolan DNA Learning Center.

The site has numerous resources for education. The quality is extremely high and the information is wonderful. Both high school and college instructors can find topics that would be useful in the class.

\section{TALKING GLOSSARY OF GENETIC TERMS}

\section{http://www.genome.gov/page.cfm?pageID=10002096}

The National Human Genome Research Institute (NHGRI) maintains an educational resources Web site. One of those resources is a talking glossary (Figure 3). To quote from the site, "The National Human Genome Research Institute (NHGRI) created the Talking Glossary of Genetic Terms to help people without scientific backgrounds understand the terms and concepts used in genetic research. Simply click on the term of interest to open a page with a wealth of information, including the term's pronunciation, audio information, images and additional links to related terms. Students, teachers and parents will find the glossary an easy-to-use, always available learning source on genetics." In 30-s to 2-min recitations, over 100 common genetic terms and concepts are described by an expert in the field. Using RealAudio Player (available at http://www.real.com/?PV=0), 25 research scientists describe terms such as diabetes, sickle cell anemia, and cDNA library. Even the Director of the Human Genome project, Dr. Francis Collins, provides some of the verbalizations. Students should find this resource useful as they can both see and hear research scientists describe in their own words the basic terms of genetics.

\section{GRAPHICS GALLERY}

\section{http://www.accessexcellence.org/AB/GG/}

Access Excellence (see Figure 4) was started 10 years ago as a web resource for teachers. The National Health Museum based in Washington, DC, has taken over the reigns of Access Excellence from Genentech, Inc., who originally started the site. The Graphics Gallery has as many visual images of molecular biology as the Talking Glossary has genetic terms. The Graphics Gallery is divided into

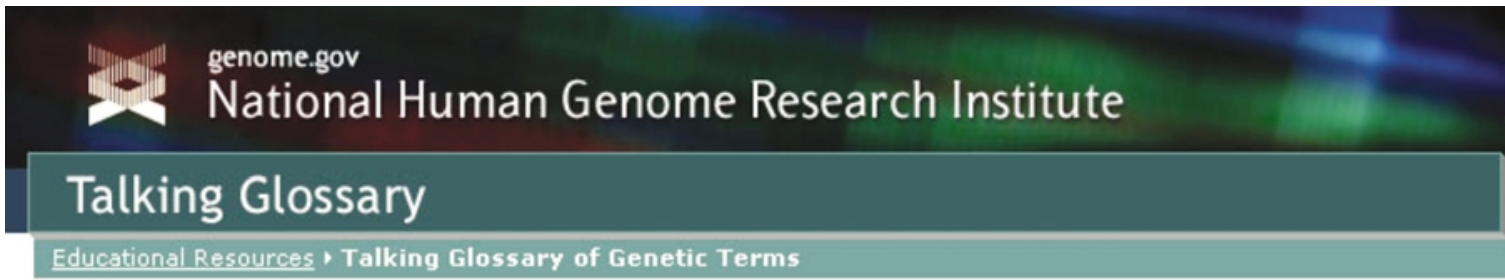

\section{Talking Glossary of Genetic Terms}

Figure 3. The National Human Genome Research Institute's Talking Glossary. 


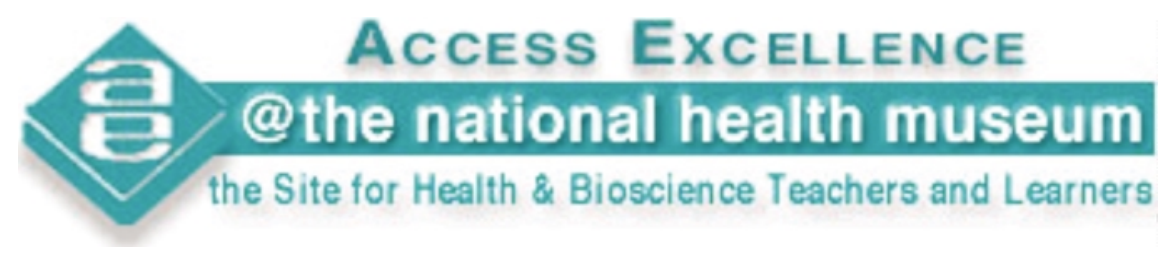

Figure 4. Access Excellence, in the Graphics Gallery.

seven sections including viruses, genetics, and biological engineering. If you are an instructor looking for an image to demonstrate a process or concept in molecular biology and genetics, this Web site is an excellent source of image information. Many of the illustrations are in color and can be downloaded as Adobe Acrobat PDF files (go to http://www.adobe.com/products/acrobat/readermain.html for a free file reader). If used only for the classroom, the image files are free to teachers. You may wish to explore aspects of the Web site other than the image gallery (for the main site go to http://www.accessexcellence. org). 